(RESEARCH ARTICLE)

\title{
Perception and awareness of people towards Covid-19 and the various methods of treatment in Nigeria
}

Akeredolu Olaniyi Ayoola *, Azeez Abeeb Abiodun, Adetunji Adekunle Sarafadeen, Arabambi Itunuoluwa Victoria, Akomolede Lucas Aderemi and Buhari Tunji Hafiz

Forestry Research Institute of Nigeria, Jericho Hill, Ibadan, Oyo State Nigeria.

Publication history: Received on 28 May 2020; revised on 11 June 2020; accepted on 14 June 2020

Article DOI: https://doi.org/10.30574/wjarr.2020.6.3.0176

\begin{abstract}
Despite the world's concerted efforts targeted at combating the novel virus, producing a potent vaccine for the cure looks a mile ahead of us. Understanding the virus and its means of transmission will go a long way to flatten the curve while we await a successful production of vaccines. This study was carried out to determine the perception and awareness of Nigerians about corona virus and the various methods of its treatment. An online version of questionnaire was sent out to respondents on questions relevant to the study, data were analyzed using descriptive statistics. Findings from the study revealed that $68 \%$ of the respondents were males while $32 \%$ were females, the modal age range was 31 40 years $(24.6 \%)$. Majority of them had Tertiary education and their perceptions about the incidence and the spread of Covid-19 indicates that they are sufficiently informed about it. Only a few (26.8\%) respondents claimed to have the knowledge about the availability of potent herbal medicines for the treatment of the virus, the herbs mentioned in this study include: Neem leaves, honey, cloves, mango leaves, turmeric, ginger and garlic, beet root, bitter leaf root, cashew leaf, olive oil, lemon, black seed oil, onion and bitter kola. One or a combination of the aforementioned herbs were claimed to have remedied Covid-19 at one point or the other. These past few months have been somewhat challenging according to the respondents, they are deprived of the basic necessities of life due to restriction on economic and social activities. This is however, not so much price to pay considering how deadly the virus is.
\end{abstract}

Keywords: Covid-19; Perception; Herbs; Novel; Vaccine; Challenges

\section{Introduction}

Corona viruses (family coronaviridae) are a group of viruses that infect both animals and humans [1]. Human corona virus disease is a respiratory infection that targets the lungs and the respiratory pathway which spreads from animal to person, person to person while sneezing or physical contact [2]. In some individuals, it is associated with mild respiratory disease with symptoms such as cold, fever, cough, sore throat and shortness of breath while in more severe cases, infection can cause pneumonia, Middle East Respiratory Syndrome (MERS) and Severe Acute Respiratory Syndrome (SARS). The world recorded the first case of this novel virus in Wuhan, Hubei Province, China in December 2019, hence the name COVID-19 [3]. Various standard preventive measures have been recommended to curtail the spread of COVID-19. These include frequent cleaning of hands using alcohol-based hand rub or soap and water, covering the nose and mouth with a flexed elbow or disposable tissue when coughing and sneezing and avoiding close contact with anyone that has a fever and cough [2].

Herbal medicines prepared from different botanicals have proven to be effective both as preventives and curatives against COVID-19 in several parts of the world, although many of these medicines are still under scrutiny. Various of reports of such medicine from many countries have been flagged by news media and online source including the more trending locally prepared drugs from countries such as China and Madagascar. Nigeria ethnomedicinal scientists from different institutions are not left out in the race and have also been making a lot of contributions in this quest for natural

\footnotetext{
* Corresponding author: Akeredolu Olaniyi Ayoola
} 
medicines and recently, some research breakthroughs on possible cures and preventive drugs for COVID 19 have emerged in the country.

Perception of an individual towards an event or a situation goes a long way to determine their attitude towards it. Since Covid-19 disease broke out in December 2019 in Wuhan, China, the world has suffered a tremendous decline in population. As at 5th of May 2020, more than 3.6 million infections have been confirmed across 187 countries worldwide, including over 250 thousand deaths and about 1.2 million recovery [4] and this menace has made it incumbent on countries to halt all social activities, economic engagements and shut their borders to visitors as well as business activities, in order to mitigate its spread. Nigeria, being one of the developing countries affected by the pandemic has been dealt a heavy blow since the index case was discovered in February, 2020. Since then the transmission has been far reaching, and the virus has spread to 35 states including the FCT Abuja. Over 2800 cases have been confirmed till date with over 400 recoveries and more than 90 deaths. The forgoing necessitated the Federal as well as state governments to shutdown activities in areas with high incidence of transmission and residents were placed on total lockdown for a period of time. Unfortunately, this did not have the desired effect, instead, the virus has been on the increase, this has forced the Government to ease the lockdown, leaving the fate of the masses in God's hands.

There are divergent perceptions about Covid-19 and applicability of herbal preparations as treatments among different sections of the Nigerian population. Regarding the pathogen, some opined that, the virus cannot thrive in countries with temperate weather conditions and as such, conceptualize its existence in Nigeria as a myth and an avenue for the government at all levels to siphon public fund, others have "the superiority complex". This second category of people believe that being the black race and having been availed several vaccines at the early stages of our lives, we are more immune to the virus than our white counterparts. For these reasons, it is therefore imperative on us as interested scientists to investigate people's perception about COVID-19 and commonly used herbal preparations in Nigeria, using a scientifically acceptable approach. This will go a long way in educating people about the true nature of the pathogen regarding its nature, modes of transmission and preventive measures, as well as herbal preparations that could serve as effective preventives and cures against the virus.

\section{Material and methods}

The study was conducted via cross-sectional online survey between the 1st and 6th of May, 2020.

\subsection{Data collection}

A well-structured anonymous questionnaire was adapted for this study to elicit relevant information from respondents, all of whom were of Nigerian descent. Relevant questions about the respondent's socioecononomic characteristics as well as their perception about Covid-19 and the various methods of treatment were contained in the questionnaire.

\subsection{Sampling technique}

Purposive sampling technique was employed in this study. This technique was preferred due to the difficulty of accessing people physically during this pandemic period. Questionnaires were purposively sent to various groups and platforms on social media. At the close of the online survey, 500 persons had responded to the questionnaires.

\subsection{Data analysis}

Data were analyzed using descriptive statistics such as tables, percentages, frequencies, ranges and charts.

\section{Results and discussion}

COVID-19 was first reported in Wuhan, China as a severe acute respiratory syndrome in December, 2019 but not until $11^{\text {th }}$ of March, 2020, the World Health Organization did not declare it as the first pandemic disease caused by corona virus after its spread had been confirmed in over 200 countries with a death rate of 5.7\% [1]

Nigeria is one of the most populated countries in Africa with more than 200 million populations. Prior to the report of the index case of corona virus in Nigeria on the 27th of February, 2020, a lot of controversies had trailed the nature, mode of transmission and applicability of herbal remedies in preventing or curing the disease. While some people believe that the disease is not in any way different etiologically from the acute malaria symptoms commonly experienced in the country, some opined that, the disease is a mere figment of imagination or a newly fabricated scam by the governments at all levels to siphon public funds. 


\subsection{Socioeconomic characteristics of respondents}

A total of five hundred individuals completed the online survey. Table 1 shows the socio-demographic characteristics of the respondents.

Table 1 Socioeconomic characteristics of respondents

\begin{tabular}{|c|c|c|}
\hline Characteristic & Frequency & Percentage \\
\hline \multicolumn{3}{|l|}{ Gender } \\
\hline Male & 340 & 68 \\
\hline Female & 160 & 32 \\
\hline Total & 500 & 100 \\
\hline \multicolumn{3}{|l|}{ Age } \\
\hline $21-30$ & 55 & 11 \\
\hline $31-40$ & 123 & 24.6 \\
\hline $41-50$ & 105 & 21 \\
\hline $51-60$ & 117 & 23.4 \\
\hline$>60$ & 100 & 20 \\
\hline Total & 500 & 100 \\
\hline \multicolumn{3}{|l|}{ Marital status } \\
\hline Single & 143 & 28.6 \\
\hline Married & 288 & 57.6 \\
\hline Divorced & 40 & 8.0 \\
\hline Widowed & 29 & 5.8 \\
\hline Total & 500 & 100 \\
\hline \multicolumn{3}{|l|}{ Tribe } \\
\hline Hausa & 76 & 15.2 \\
\hline Igbo & 120 & 24.0 \\
\hline Yoruba & 304 & 60.8 \\
\hline Total & 500 & 100 \\
\hline \multicolumn{3}{|l|}{ Educational level } \\
\hline Tertiary & 420 & 84 \\
\hline Secondary & 80 & 16 \\
\hline Total & 500 & 100 \\
\hline
\end{tabular}

The age class 31-40 years with the highest frequency (24.6\%) of representation was closely followed by 51-60, 41-50 and 60 and above years with $23.4 \%, 21.0 \%$ and $20.0 \%$ frequencies respectively. Whereas, the least frequency (11.0\%) was recorded for 21-30 years. The highest number of the participants (57.6\%) were married, $28.6 \%$ single, $8.0 \%$ were divorced and 5.8\% representing the least category were widowed. Majority $(60.8 \%)$ of the respondent s were Yoruba while the Igbos and Hausas were represented by $20.4 \%$ and $15.2 \%$ respectively. Most of the participants (84\%) had tertiary education whereas the rest $(16 \%)$ had only secondary education. 


\subsection{Perception of respondents about Covid-19 and the various methods of treatment}

Perception of respondents about the incidence of COVID-19, response of the Government and the various methods of treatments are shown in Table 2. Generally, across the respondents surveyed, perceptions toward the relevant information inquired varied with respect to the questions. While some individuals were positive, some people's decisions remained undecided while others were negative across the range of questions.

Table 2 Perception of respondents about Covid-19 and the various methods of treatment

\begin{tabular}{|c|c|c|c|c|c|c|}
\hline $\mathbf{S} / \mathbf{N}$ & Perceptional statements & $\begin{array}{l}\text { Resp } \\
\text { SA }\end{array}$ & A & $\mathbf{U}$ & D & SD \\
\hline 1 & $\begin{array}{l}\text { The virus is a biological warfare targeted at reducing } \\
\text { the world population }\end{array}$ & 10.7 & 30.4 & 23.2 & 28.6 & 7.1 \\
\hline 2 & $\begin{array}{l}\text { The virus originated from animals but was later } \\
\text { transmitted to man }\end{array}$ & 15.3 & 40.7 & 18.2 & 24.6 & 1.2 \\
\hline 3 & $\begin{array}{l}\text { Covid-19 is a scam in Nigeria, the Government is only } \\
\text { using it to siphon fund }\end{array}$ & 0.0 & 7.1 & 30.4 & 30.4 & 32.1 \\
\hline 4 & $\begin{array}{l}\text { The virus is a punishment from God for } \\
\text { sins. }\end{array}$ & 0.0 & 10.2 & 21.7 & 35.6 & 32.5 \\
\hline 5 & $\begin{array}{l}\text { Sneezing, coughing, high body temperature } \\
\text { and short breath are all symptoms of Covid-19 }\end{array}$ & 40.3 & 25.5 & 15.6 & 13.8 & 4.8 \\
\hline 6 & $\begin{array}{l}\text { The Government is doing enough to curtail the } \\
\text { spread of the Virus within the country }\end{array}$ & 7.3 & 23.6 & 12.7 & 45.5 & 10.9 \\
\hline 7 & $\begin{array}{l}\text { The Government has sufficiently invested } \\
\text { research aimed at producing Covid-19 vaccine }\end{array}$ & 0.0 & 17.9 & 16.1 & 33.9 & 32.1 \\
\hline 8 & $\begin{array}{l}\text { The lockdown imposed on citizens have had a positive } \\
\text { impact in reducing the spread of the virus. }\end{array}$ & 16.1 & 37.5 & 19.6 & 26.8 & 0.0 \\
\hline 9 & $\begin{array}{l}\text { The palliative measures put in place by the for } \\
\text { citizens has so far had the intended effect }\end{array}$ & 0.0 & 14.3 & 7.1 & 33.9 & 42.9 \\
\hline 10 & $\begin{array}{l}\text { Cloroquine and other Orthodox antiviral } \\
\text { drugs have so far been effective in the combat against } \\
\text { Covid-19 }\end{array}$ & 0.0 & 25.0 & 50.0 & 16.1 & 8.9 \\
\hline 11 & $\begin{array}{l}\text { Unapproved and locally formulated herbs } \\
\text { curing the virus }\end{array}$ & 23.2 & 35.7 & 23.2 & 10.7 & 7.2 \\
\hline 12 & $\begin{array}{l}\text { These locally made herbs are potent, and } \\
\text { their use should be approved nationwide by the FG }\end{array}$ & 33.9 & 26.8 & 30.4 & 8.9 & 0.0 \\
\hline 13 & $\begin{array}{l}\text { The Health sector is adequately equipped } \\
\text { tackle the pandemic }\end{array}$ & 10.9 & 12.6 & 20.7 & 25.4 & 30.4 \\
\hline 14 & $\begin{array}{l}\text { So far, the use of alcohol based hand } \\
\text { has been effective in fighting Covid-19 }\end{array}$ & 25.4 & 40.3 & 23.2 & 11.1 & 0.0 \\
\hline 15 & $\begin{array}{l}\text { The introduction of compulsory use of facemask has } \\
\text { had a positive effect in fight against the virus }\end{array}$ & 13.6 & 20.1 & 17.3 & 35.4 & 13.6 \\
\hline
\end{tabular}

SA- Strongly agree, A- Agree, U- Undecided, D- Disagree, SD- Strongly disagree

The responses received through the fielded questions indicated that there are considerable variations in the perceptions hold by different categories of individuals in the country regarding this pandemic. Some sets of people opined that the disease is a biological warfare created to trim down the ever-growing world population. The study revealed that, $30.4 \%$ of the number of individuals encountered in the survey agrees that with the assertion. Similarly, most of the respondents 
conform to the idea that the virus originated from animals and through contacts, was transmitted to man. Also, majority of the respondents disagree with the notion that, the disease is a punishment from God for the sin of mankind. Well above average of the total number of respondents $(65.8 \%)$ share in the opinion that, sneezing, coughing, high body temperature and short breath are all symptoms of the disease whereas only less than 35\% dissent from this popular belief. About sixty-percent of the respondents are of the opinion that, the Government is not doing enough in terms of prevention and finance of research work needed to develop vaccines against the virus. While the government at all levels continue to embrace the idea of lockdown as a laudable strategy to mitigate the spread of the disease, the outcome of this research has proven that, only slightly above the average of the population of the respondents agreed that the lockdown had produced a positive impact. Similarly, more than three-quarter (76.8\%) of the respondents did not perceive the palliative measures put in place by the Government as effective. Also the popular notion that the common anti-malaria drug, chloroquine and some orthodox anti-viral drugs reported for the treatment of the disease in many countries including Nigeria was widely accepted. However, more than half of the population (58.9\%) supported the efficacy of the various unapproved and locally formulated herbs in the treatment of the disease and around $60 \%$ agree that the locally made herbs are potent and should be approved for the treatment of the disease.

According to the survey, about 58\% of the respondents posited that the medical facilities required for the management of the disease are currently lacking in Nigeria health sector. However, majority of the respondents (65.7\%) agreed to the effectiveness of alcohol-based hand sanitizers in combating the spread of the disease. On the contrary, the use of face-masks which is also a preventive measure against the spread of the virus was not supported my almost half of the respondents.

\subsection{Awareness of respondents about available herbal remedies for Covid-19}

The level of awareness of respondents about availability of herbal remedies is presented in Table 3. About one-quarter $(26.8 \%)$ of the respondents were aware while around three-quarter $(73.2 \%)$ were unaware that herbal remedies are available for the treatment of the deadly disease.

Table 3 Distribution of respondents according to their awareness about available herbal remedies for Covid-19

\begin{tabular}{lll}
\hline Awareness Status & Frequency & Percentage \\
\hline Aware & 134 & 26.8 \\
Unaware & 366 & 73.2 \\
Total & 500 & 100 \\
\hline
\end{tabular}

This research revealed that, although various botanicals were touted in the public and on social media as effective remedies against the disease, only around one-quarter of the respondents are aware of such development whereas about three-quarter of the respondents claimed to be unaware

\subsection{Distribution of herbal ingredients used to combat Covid-19}

Among various botanicals used as herbal remedies documented in the survey, ginger and garlic was the most mentioned with frequency of $15 \%$ and was closely followed by lemon with $14 \%$ while the least mentioned were onion (2\%) and mango leaf (2\%) (Fig.1). 


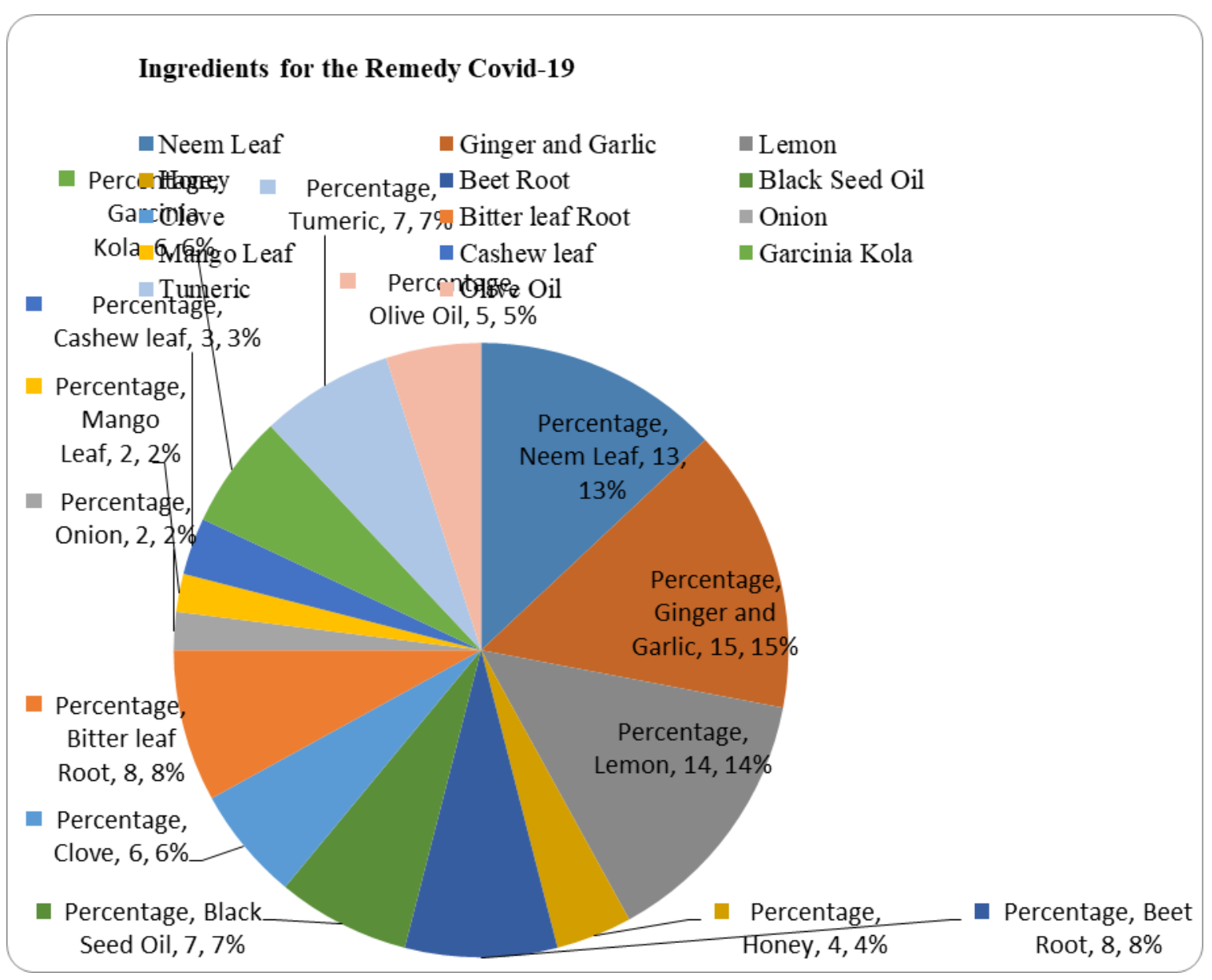

Figure 1 Distribution of Herbal Ingredients Used to Combat Covid-19

It is widely accepted that, diversity of plants can be harnessed in the treatments of any kind of ailment affecting mankind. Under six months that COVID-19 had become pandemic and the most popular disease all over the world, quests for cures and preventives from natural origin most especially, plant sources had been a global target among research scientists in the field of ethno-botany and other related fields, medical practitioners and native doctors in various part of the world.

The survey conducted paved way for the discovery of some of the botanicals used as herbs in Nigeria for prevention and treatment of COVID-19. These botanicals are neem leaves, honey, cloves, mango leaves, turmeric, ginger and garlic, beet root, bitter leaf root, cashew leaf, olive oil, lemon, black seed oil, onion and bitter kola. It is obvious that these natural remedies have different popularities as remedies for the treatment of this disease. To exemplify, garlic and ginger, lemon and neem leaves were well mentioned investigated the anti-microbial properties of some of these botanicals and most of them are currently in use in folk medicine and pharmaceutical industries for the production of various anti-microbial drugs for treating various ailments. Findings from this research will provide basic information for individuals as well as research scientists who may be willing to study or carry out research on the disease and the botanicals.

\subsection{Challenges faced by respondents since the outbreak of Covid-19}

The deprivations experienced by the respondents are revealed on table 4. One thing is constant, this imposed lockdown has incapacitated respondents of the study one way or the other. These challenges range from hunger and starvation to insecurity of lives and properties, to economic upturn, this is to mention a few. 
Table 4 Challenges faced by respondents since the outbreak of Covid-19

\begin{tabular}{|c|c|c|}
\hline Challenge(s) faced & Frequency & Rank \\
\hline Hunger and Starvation & 412 & $1^{\text {st }}$ \\
\hline Increase in the price of goods and services & 333 & $2^{\text {nd }}$ \\
\hline Economic down turn & 319 & $3^{\text {rd }}$ \\
\hline $\begin{array}{l}\text { Insecurity stemming from increased crime } \\
\text { rate }\end{array}$ & 301 & $4^{\text {th }}$ \\
\hline $\begin{array}{l}\text { Inability to meet basic financial obligation } \\
\text { due to the pause in economic activities }\end{array}$ & 273 & $5^{\text {th }}$ \\
\hline $\begin{array}{l}\text { Inability to attend social and religious } \\
\text { gatherings }\end{array}$ & 264 & $6^{\text {th }}$ \\
\hline $\begin{array}{l}\text { Lack of palliative measures to the poor and } \\
\text { vulnerable }\end{array}$ & 260 & $7^{\text {th }}$ \\
\hline $\begin{array}{l}\text { Downsizing of employees by private } \\
\text { organizations due to lockdown }\end{array}$ & 245 & $8^{\text {th }}$ \\
\hline Fear of Community transmission of Covid-19 & 220 & $9^{\text {th }}$ \\
\hline $\begin{array}{l}\text { Health related challenges unrelated to Covid- } \\
19\end{array}$ & 195 & $10^{\text {th }}$ \\
\hline Restriction of free movement & 183 & $11^{\text {th }}$ \\
\hline Psychological and physical trauma & 175 & $12^{\text {th }}$ \\
\hline Boredom & 172 & $13^{\text {th }}$ \\
\hline $\begin{array}{l}\text { Ineffectiveness of Security operatives in their } \\
\text { in their discharge of duty }\end{array}$ & 148 & $14^{\text {th }}$ \\
\hline $\begin{array}{l}\text { Lack of transparency by the government in } \\
\text { the fight against the virus }\end{array}$ & 119 & $15^{\text {th }}$ \\
\hline
\end{tabular}

The challenges encountered by the respondents (ranked from $1^{\text {st }}$ to $15^{\text {th }}$ positions) since the outbreak are represented in Table 4. The most prevalent (1 $1^{\text {st }}$ positioned with frequency of 412 out of 500) of these challenges was hunger and starvation while the least common ( $15^{\text {th }}$ positioned with frequency of 119 out of 500) was lack of transparency by the Government in fighting against the virus.

\section{Conclusion}

This survey has revealed as much as possible, the perception of the public regarding the existence of Corona virus and the various ethnomedicinal herbs, potent in combating the pandemic outbreak. One thing is sacrosanct, people are well aware about the virus and the danger it poses, most of these people also feel that the Government at all levels could do better in combating the menace, some suggested the herbal solutions that can help in treating the symptoms of Covid19. The virus is exponentially on a daily basis, ravaging the world as we know it. It is our collective responsibility to flatten the curve and reclaim our freedom from this deadly novel virus.

\section{Compliance with ethical standards}

\section{Acknowledgments}

The Authors will like to thank all respondents involved in this study for making out their time despite the pandemic. 


\section{Disclosure of conflict of interest}

The Authors declare no conflict of interest.

\section{Statement of informed consent}

Informed consent was obtained by the authors from all individual respondents included in the study.

\section{References}

[1] The World Health Organization Q\&A on corona viruses (COVID-19) (2020).

[2] Tanya D and Ayush S. (2020). Use of Herbal Medicine on Corona virus. Acta Scientific Pharmaceutical Sciences, 4 (4), 61-63.

[3] Chen N, Zhou M, Dong X, Qu J, Gong F, Hang Y, Qiu Y, Wang J, Liu Y, Wei Y, Xia J, Yu T, Zhang X and Zhang L. (2020). Epidemiological and clinical characteristics of 99 cases of 2019 novel coronavirus pneumonia in Wuhan, China: a descriptive study. Lancet, 395(10223), 507-13.

[4] Corona virus: Which countries have confirmed cases? https://www.aljazeera.com/news/2020/01/countriesconfirmed-cases- 200125070959786.html

\section{How to cite this article}

Akeredolu OA, Azeez AA, Adetunji AS, Arabambi IV, Akomolede LA and Buhari TH. (2020). Perception and awareness of people towards Covid- 19 and the various methods of treatment in Nigeria. World Journal of Advanced Research and Reviews, 6(3), 78-85. 